\title{
Articulo Original / Original Article \\ Ilex paraguariensis: the effect of genotypes and growth phase on biomass, secondary metabolism and antioxidant activity of in vitro cultivated calli
}

\author{
[Ilex paraguariensis: el efecto de los genotipos y la fase de crecimiento sobre la biomasa, metabolismo \\ secundario y la actividad antioxidante de los callos cultivados in vitro]
}

\author{
Renata Lúcia Grunennvaldt ${ }^{1,3}$, Juliana Degenhardt-Goldbach ${ }^{2}$, Jéssica de Cássia Tomasi ${ }^{1}$, Fabrício Augusto Hansel ${ }^{2}$, \\ Bruno Portela Brasileiro ${ }^{1}$, Peter Brooks ${ }^{3}$, Erik Nunes Gomes ${ }^{1,4}$, Überson Boaretto Rossa ${ }^{5}$ \& Cícero Deschamps ${ }^{1}$ \\ ${ }^{1}$ Department of Crop Sciences, Federal University of Parana, Curitiba, PR, Brazil \\ ${ }^{2}$ National Centre of Forestry Research, Colombo, PR, Brazil \\ ${ }^{3}$ University of The Sunshine Coast. Sippy Downs, QLD, Australia \\ ${ }^{4}$ CAPES Foundation, Ministry of Education of Brazil, Brasília, DF, Brazil \\ ${ }^{5}$ Departament of Agrarian Sciences, Federal Institute Catarinense, Araquari, SC, Brazil
}

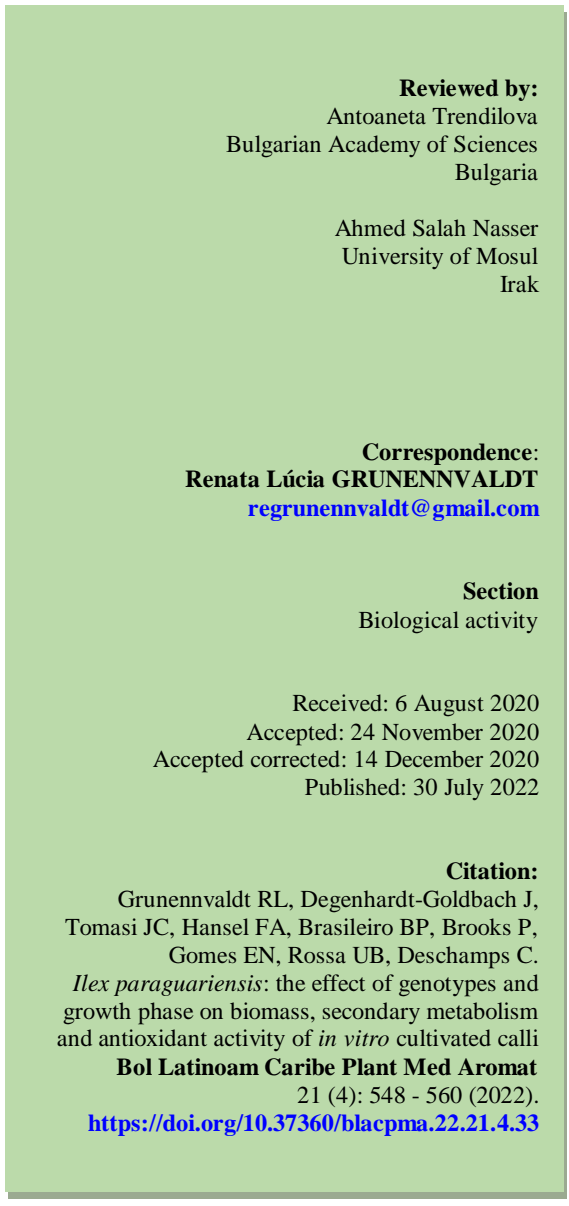

Abstract: Yerba mate (Ilex paraguariensis) produces several secondary metabolites of interest to the pharmaceutical industry, such as chlorogenic acids and methylxanthines. These compounds have been produced in vitro by callus culture from different species. However, for I. paraguariensis, no studies upon the production of these compounds in vitro have been performed to date. In this work, we show that the concentration of secondary metabolites from I. paraguariensis callus is possible and highly dependent on the callus growth phase. We observed that the best phase for the production of secondary compounds in calli of yerba mate is the stationary growth phase on both genotypes tested. In this phase, higher levels of phenolic compounds, chlorogenic acid and 3,5-dicaffeoylquinic acid and greater antioxidant activity were observed. Chlorogenic acid and 3,5-dicaffeoylquinic acid presented positive correlation with antioxidant activity. For the first time, secondary compounds were reported in yerba mate calli cultivated in vitro.

Keywords: Callus culture; Yerba mate; Methylxanthines; Stationary phase; Phenolic compounds

Resumen: La yerba mate (Ilex paraguariensis) produce varios metabolitos secundarios de interés para la industria farmacéutica, como los ácidos clorogénicos y las metilxantinas. Estos compuestos se han producido in vitro mediante cultivo de callos de diferentes especies. Sin embargo, para I. paraguariensis, hasta la fecha no se han realizado estudios sobre la producción de estos compuestos in vitro. En este trabajo, mostramos que la concentración de metabolitos secundarios desde callos de I. paraguariensis es posible y altamente dependiente de la fase de crecimiento del callo. Observamos que la mejor fase para la producción de compuestos secundarios en callos de yerba mate es la fase de crecimiento estacionario en ambos genotipos probados. En esta fase se observaron niveles más altos de compuestos fenólicos, ácido clorogénico y ácido 3,5-dicafeoilquínico y una mayor actividad antioxidante. El ácido clorogénico y el ácido 3,5-dicafeoilquínico presentaron correlación positiva con la actividad antioxidante. Por primera vez, se reportaron compuestos secundarios en callos de yerba mate cultivados in vitro.

Palabras clave: Cultivo de callos; Yerba mate; Metilxantinas; Fase estacionaria; Compuestos fenólicos 


\section{INTRODUCTION}

Yerba mate (Ilex paraguariensis) is a plant of remarkable potential for uses in both the cosmetic and pharmaceutical industries, due to the production of valuable bioactive secondary metabolites, such as caffeine, theobromine and caffeoylquinic acids (Cardozo Junior \& Morand, 2016).

One of the most popular non-alcoholic drinks in South America, yerba mate tea is becoming increasingly popular in Europe and the United States due to its health properties (Mejía et al., 2010), mainly related to antioxidant activities, evidenced both in chemical and biological systems, including clinical trials (Gugliucci, 1996; Matsumoto et al., 2009).

One major issue to the production of commercially important products in yerba mate and other species refers to the effects of seasonality and the environment on the accumulation of secondary metabolites (Esmelindro et al., 2004; Freitas et al., 2018). Due to the need for environmental control, the interest in the development of technologies for the production of phytochemicals in vitro has increased, and some companies have been using plant cells grown under controlled conditions for cosmetics manufacturing (PhytoCellTec, 2012; Trehran et al., 2017). In addition, several studies have been conducted on producing secondary metabolites from in vitro cultured cells and plant organs for health promotion (Verardo et al., 2016). In this sense, callus culture of $I$. paraguariensis may represent a viable approach for the production of medicinally important compounds under controlled environmental conditions.

In the present study, we assessed the antioxidant activity as well as the contents of secondary compounds, such as polyphenols and methylxanthines, in calli from two genotypes of yerba mate (F1 and 6-156-) in different phases of growth, aiming to assess the feasibility of producing important secondary metabolites of yerba mate in vitro through callus culture.

\section{MATERIAL AND METHODS \\ Plant material and growth conditions}

Two elite clones, F1 and 6-156-6, from the breeding program developed by EMBRAPA Forestry (Brazilian Agricultural Research Corporation) (Resende et al., 2000) were used as source of plant material for callus induction. The plants were grown under greenhouse conditions in mini-clonal hedges on a semi-hydroponic channel system with sand beds.

The $2^{\text {nd }}$ or $3^{\text {rd }}$ pair of young leaves from parent plants were collected and immersed in antioxidant solution $\left(0.5\right.$ g. $\mathrm{L}^{-1}$ of ascorbic acid and 0.5 g. $\mathrm{L}^{-1}$ of citric acid). Subsequently, the leaves were washed with a neutral detergent in tap water, followed by immersion in Cercobin ${ }^{\circledR}$ fungicide solution (1 g. $\left.\mathrm{L}^{-1}\right)$ for $10 \mathrm{~min}$ and immersion in mercury chloride $(0.05 \%)$ for $5 \mathrm{~min}$, followed by rinsing three times with sterilized water. The entire asepsis procedure was performed in a laminar flow hood.

Leaf discs of $2 \mathrm{~cm}$ diameter were cut with the aid of a metal punch and placed with the adaxial face in contact with $1 / 4$ MS media (Murashige \& Skoog, 1964), plus 7 g.L.-1 agar, 3\% sucrose, $4.52 \mu \mathrm{M}$ 2,4dichlorophenoxyacetic acid (2,4-D) and $4.56 \mu \mathrm{M}$ zeatin, as described by Stachevski et al. (2013). The $\mathrm{pH}$ of the culture medium was adjusted to $5.8 \pm 0.2$, autoclaved and dispensed into Petri dishes $(100 \times 15$ $\mathrm{mm})$. Ten Petri dishes containing five leaf explants each were kept in the dark at $23 \pm 2{ }^{\circ} \mathrm{C}$ throughout the growing period, and the explants were transferred to fresh media every 30 days.

\section{Analysis of calli growth}

Calli growth curve was established by plotting fresh weight values of 10 calli measured every 15 days from time 0 to 150 days of culture. The percentage of callus growth was determined according to Santos et al. (2008) using the following equation:

\section{\% growth $=[(P f-P i) / P f)]^{* 100}$}

\section{where: $\boldsymbol{P} \boldsymbol{i}=$ initial weight and $\boldsymbol{P f}=$ final callus weight.}

\section{Preparation of extracts from yerba mate calli}

Leaves (initial condition) and callus at 75, 90, 105, 120,135 and 150 days of culture were assessed regarding total phenolic compounds, antioxidant activity and the content of secondary metabolites.
The experimental unit was composed of 10 Petri dishes with five calli per plate. In each period, three calli were randomly selected for preparation of the extracts. The leaves subjected to biochemical analysis were immediately immersed in liquid nitrogen after 
harvest. All samples, leaves and calli, were stored in a freezer at $-80^{\circ} \mathrm{C}$ until the preparation of the extracts. The samples were macerated in liquid nitrogen and then lyophilized for $72 \mathrm{~h}$.

The lyophilized samples $\left(10 \mathrm{mg} \cdot \mathrm{mL}^{-1}\right.$ of callus and $5 \mathrm{mg} \cdot \mathrm{mL}^{-1}$ of leaves) were extracted with water: ethanol (1:1) solution. The extracts were vortexed for 30 sand subsequently sonication for 30 s. The extraction was performed for $1 \mathrm{~h}$ at $60^{\circ} \mathrm{C}$, with rotation at $450 \mathrm{rpm}$ in Thermomixer $^{\circledR}$ equipment. After this period the solution was centrifuged for 40 min at $13000 \mathrm{rpm}$. The solution was filtered through a 2 micron filter. Part of the solution was used for the biochemical analyses (phenolic compounds and antioxidant activity) while the other part $(500 \mu \mathrm{L})$ was transferred into a vial, where, subsequently, 2.5 $\mu \mathrm{L}$ of the internal umbelliferone $\left(10 \mathrm{mg} \cdot \mathrm{mL}^{-1}\right)$ standard (Sigma $\left.{ }^{\circledR}\right)$ was added for HPLC analysis.

\section{Identification and quantification of secondary compounds by HPLC-UV}

Chromatographic analyzes were conducted on a Shimadzu liquid chromatograph (UFLC), controlled by LC solution Software and equipped with automatic injector and UV detector (SPD-20A). The samples $(20 \mu \mathrm{L})$ were separated on a Shim-Pack CLC- ODS (M) $(250 \times 4.6$ mm.d.i. $5 \mu \mathrm{m})$ column, protected by a Shim-Pack CLC G-ODS $(10 \times 4.0$ mm.d.i. $5 \mu \mathrm{m})$ pre column and with water $(99 \%)$ acetic acid (1\%) solution (solvent A) and 100\% acetonitrile (solvent B) as the mobile phase. The flow rate was $0.5 \mathrm{~mL} \cdot \mathrm{min}^{-1}$, with the following gradient mode: $0-15 \min (3 \% \mathrm{~B}), 15-20 \mathrm{~min}(3 \%-20 \% \mathrm{~B}), 20$ $40 \min (20 \% \mathrm{~B}), 40-45 \mathrm{~min}(20-30 \% \mathrm{~B}), 45-55 \mathrm{~min}$ (30\%-100\% B), 55-75 (100\% B), 75-80 min (100-3\% B) and $80-95 \min (3 \% \mathrm{~B})$.

The spectra of compounds were recorded at $280 \mathrm{~nm}$, with the temperature at $30^{\circ} \mathrm{C}$. The identification of secondary compounds was carried out based on the retention time of corresponding external standards. The semi-quantification of the compounds was performed by the ratio between the analyte areas and the internal umbelliferone standard.

The sample concentration was expressed in $\mathrm{mg}$ of the compound per gram of dry sample (mg. $\left.\mathrm{g}^{-1}\right)$. For the identification of the compounds in the extracts, standard solutions $\left(\operatorname{Sigma}^{\circledR}\right)$ of theobromine, caffeine, chlorogenic acid, and 3,5-dicaffeoylquinic acid were used.
The LC-MS/MS confirmation of the compounds utilized the SCIEX X500R QTOF system with Turbo $V^{\mathrm{TM}}$ source and Electrospray Ionization (ESI) was used in positive and negative polarity. IS voltage was set to $5500 \mathrm{~V}$. The extracts $(2 \mu \mathrm{L})$ were separated on LC Synergy Fusion-RP 80A (75 x 4.6 $\mathrm{mm}$, d.i. $4 \mu \mathrm{m}$ ) column, protected by LC pre column, using a mobile phase (A- water, acetonitrile, formic acid- 94.9:5:0.1 and B- acetonitrile, formic acid99:0.1), flow rate $0.5 \mathrm{~mL} \cdot \mathrm{min}^{-1}$ in the following gradient mode: $0-3 \mathrm{~min}(0 \% \mathrm{~B}), 3-23 \mathrm{~min}(0 \%-3 \%$ B), $23-28 \min (30 \%-100 \% \mathrm{~B}), 28-30 \mathrm{~min}(100 \% \mathrm{~B})$, $30-31 \mathrm{~min}(100 \%-0 \% \mathrm{~B}), 31-35 \mathrm{~min}(0 \% \mathrm{~B})$.

\section{Determination of the total phenol content}

The phenol content was determined by the spectrophotometric method of Folin-Ciocalteau (Horžić et al., 2009) with modifications. In a glass test tube, $6.0 \mathrm{~mL}$ of water, followed by $0.5 \mathrm{~mL}$ of the Folin-Ciocalteau reagent were added to a $0.1 \mathrm{~mL}$ aliquot of the calli extract from each experimental unit. The mixture was then agitated and incubated for $5 \mathrm{~min}$ at room temperature. Thereafter, $2 \mathrm{~mL}$ of aqueous $\mathrm{Na}_{2} \mathrm{CO}_{3}(15 \%)$ solution was added to the mixture. The final volume was adjusted to $10 \mathrm{~mL}$ and, after $2 \mathrm{~h}$, the samples absorbances were measured at $760 \mathrm{~nm}$ in Shimadzu-1800 UV/VIS spectrophotometer. The total phenol content was obtained through an analytical curve plotted with gallic acid in the range of $0.25-10 \mathrm{mg} . \mathrm{L}^{-1}$. The results were expressed in milligrams of gallic acid equivalent per gram of dried plant extract $\left(\right.$ mgGAE.g $\left.{ }^{-1}\right)$.

\section{Determination of antioxidant activity}

Leaves and calli extracts were tested for the scavenging effect on 2,2-diphenyl-1-picrylhydrazyl (DPPH) radicals, according to the method of BrandWillians et al. (1995). The extract (1 mL) was added to $3.9 \mathrm{~mL}$ of $\left(6 \times 10^{-5}\right.$ mol. $\left.\mathrm{L}^{-1}\right)$ DPPH methanol solution. The mixture was shaken vigorously and incubated for $30 \mathrm{~min}$ at room temperature. After this period, the absorbance was determined at $517 \mathrm{~nm}$ in a UV-VIS spectrophotometer (Shimadzu-1800).

The antioxidant activity was quantified through analytical curve of Trolox in the range of 0 $1000 \mathrm{mg} . \mathrm{L}^{-1}$. The results were expressed in $\mu$ moles of Trolox equivalents per gram of dried sample $\left(\mu\right.$ molTE. $\left.\mathrm{g}^{-1}\right)$. The DPPH radical scavenging activity $(S \%)$ was calculated using the following equation:

\section{Boletín Latinoamericano y del Caribe de Plantas Medicinales y Aromáticas / 550}




$$
S \%=\left(\left(\mathrm{A}_{515(\mathrm{C})}-\mathrm{A}_{515(\mathrm{~A})}\right) / \mathrm{A}_{515(\mathrm{C})}\right) * 100
$$

Where, $A_{515(C)}$ is the absorbance of the blank control (containing all reagents except the extract solution) and $A_{515(A)}$ is the absorbance of the test sample, both at $515 \mathrm{~nm}$.

\section{Experimental design and statistical analysis}

The experimental design was completely randomized in a split-plot scheme to evaluate callus growth. Ten replicates were used to evaluate the fresh callus weight, with the two clones being the plots and the times in the subplots. The analysis of total phenolic compounds, antioxidant activity and secondary metabolites quantifications, was performed considering a completely randomized design in a $2 \times 6$ factorial scheme, with two clones and 6 culture times, with three replications. Variance homogeneity was assessed by the Bartlett test and the data were submitted to analysis of variance (ANOVA). When significant, the means were compared by Tukey's test $(p<0.01$ and $p<0.05) \mathrm{d}$ for the variable of callus fresh weight. Regression analysis $(p<0.01$ and $p<0.05)$ was performed to the variables total phenolic compounds, antioxidant activity, and the relative percentage of theobromine, caffeine, chlorogenic acid and 3,5dicaffeoylquinic. The T-test was performed to compare the accumulation of secondary compounds between the two clones. The statistical analyses were performed using the ASSISTAT $^{\circledR}$ software (Silva \& Azevedo, 2016).

\section{RESULTS AND DISCUSSION \\ Calli growth curve}

During the growth kinetics, calli of both F1 and 6156-6 clones had a compact appearance and a light yellow color, which did not change throughout the growth period (Figure No. 1).

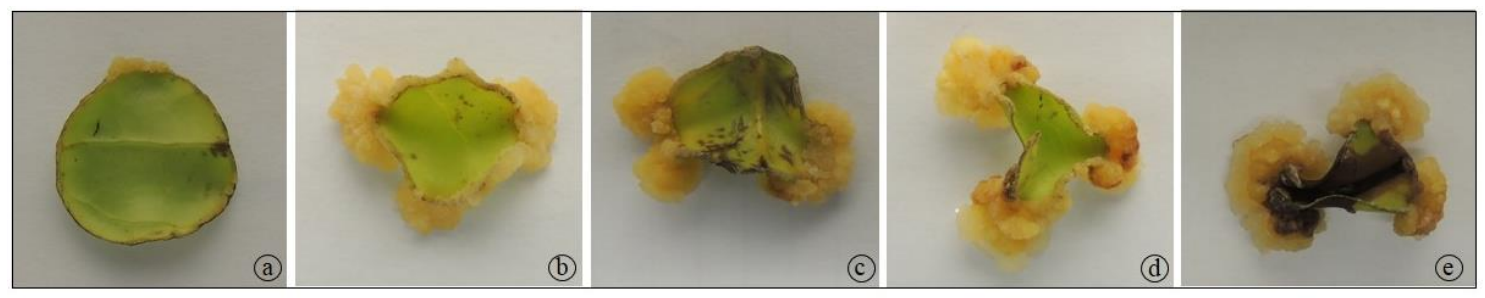

Figure No. 1

Aspects of yerba mate callus growth (6-156-6 clone). Appearance of the calli during the growth phases: a-lag, b- exponential, c- linear, d- deceleration and e-stationary

The F1 clone was more responsive to growth, with higher fresh weight from 45 days to the end of

the growth period $(p<0.01)$ (Table No. 1).

Table No. 1

Fresh weight of calli from F1 and 6-156-6 yerba mate clones at different growth periods

Callus fresh weight (mg) by period (days)

\begin{tabular}{|c|c|c|c|c|c|c|c|c|c|c|c|c|}
\hline \multirow[t]{2}{*}{ Clone } & & & & & & & & & & & & \\
\hline & 0 & 15 & 30 & 45 & 60 & 75 & 90 & 105 & 120 & 135 & 150 & CV\% \\
\hline \multirow{2}{*}{ F1 } & 45.4 & 77 & 118.1 & 138.2 & 149.4 & 196.9 & 328.2 & 380.2 & 400.2 & 410.2 & 415.2 & \multirow[b]{2}{*}{58.36} \\
\hline & Af & Aef & Ade & Ad & Acd & Ac & $\mathrm{Ab}$ & Aab & Aa & Aa & $\mathrm{Aa}$ & \\
\hline \multirow{2}{*}{$6-156-6$} & 51.1 & 68.3 & 78.2 & 88.6 & 95 & 143.8 & 245.8 & 273.3 & 293.3 & 303.3 & 308.3 & \multirow{2}{*}{18.96} \\
\hline & Ad & Ad & Ad & Bcd & Bcd & $\mathrm{Bc}$ & $\mathrm{Bb}$ & $\mathrm{Bab}$ & $\mathrm{Bab}$ & $\mathrm{Bab}$ & $\mathrm{Ba}$ & \\
\hline
\end{tabular}

Means followed by the same letter are not statistically different at 0.01 probability level according to Tukey test (uppercase letters for clones and lowercase for the time of growth) 
Growth curves plotted with calli fresh weight presented a sigmoid pattern for both yerba mate genotypes (Figure No. 2). The curves show five distinct phases during the analyzed period (0 to 150 days): lag, exponential, linear, deceleration and stationary, as previously described by Smith (1992)

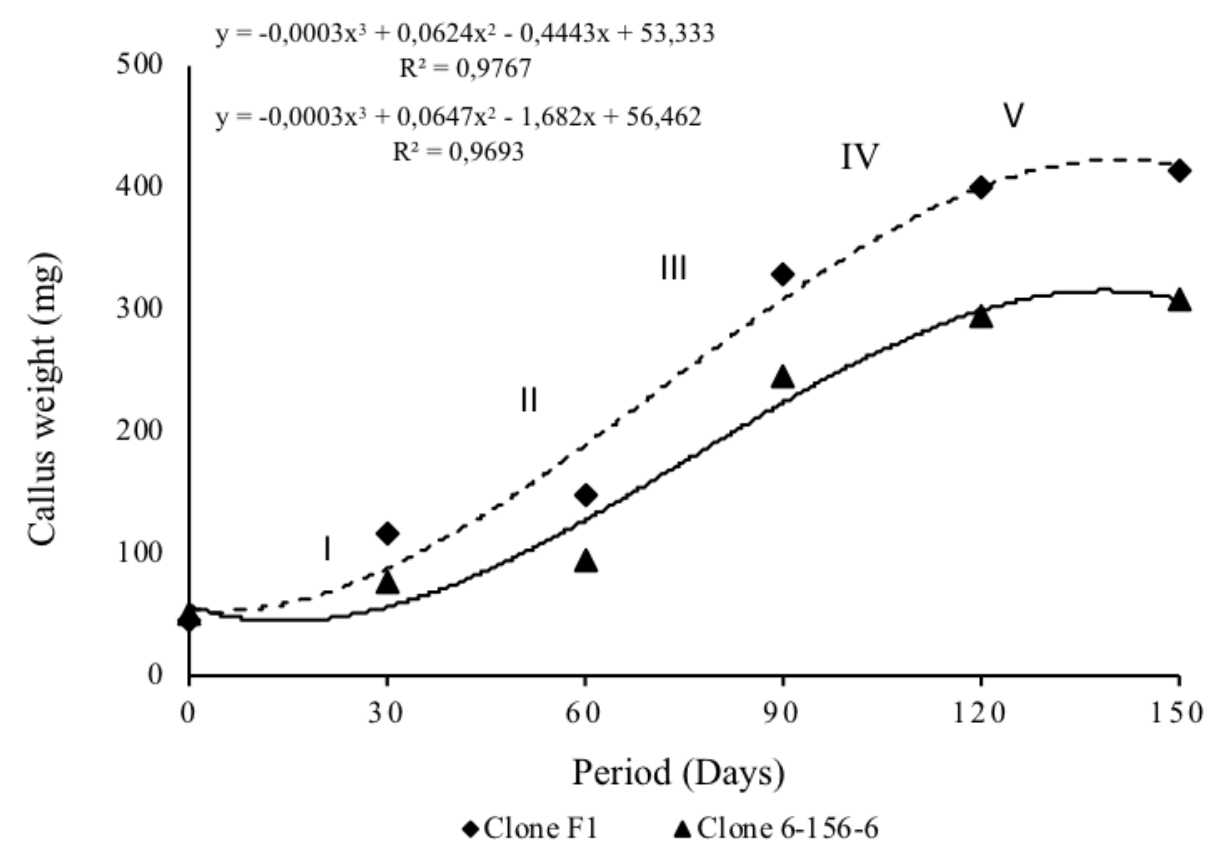

Figure No. 2

Growth curves of calli from two yerba mate clones. Phases: I - lag, II - exponential, III - linear, IV - deceleration, V - stationary

The lag phase (I) is the one in which the explant cells are prepared for cell division, characterized by the small accumulation of fresh weight in the calli. In the present study it was observed from day 0 until the $15^{\text {th }}$ day on culture media, with relatively slow growth (F1: 41.0\%, 6156-6: $25.1 \%$ ). The duration of the lag phase varies according to the species, taking, for example, up to 42 days in callus of Coffea arabica L. cultivar Rubi (Santos et al., 2003) and 15 days for Jatropha curca callus (Feitosa et al., 2013).

The exponential growth phase (II), period when the maximum cell division occurs, was observed from the $15^{\text {th }}$ day to the $75^{\text {th }}$ day of culture. A similar period was observed in Jatropha curcas callus $\left(10^{\text {th }}\right.$ to $60^{\text {th }}$ day) (Costa et al., 2015). In this period, the largest increase in biomass occurred, $62.5 \%$ and $52.5 \%$ for $\mathrm{F} 1$ and 6-156-6 clones, respectively.

The linear phase (III), period in which there is decrease of the division and increase of the cellular area, was verified between the $75^{\text {th }}$ and $105^{\text {th }}$ days of culture. During this period, intense cellular proliferation was observed, and the increase in biomass was $45.9 \%$ and $47.3 \%$ for $\mathrm{F} 1$ and $6-156-6$ clones, respectively. In the same phase, Tabebuia roseo-alba calli biomass increased by $57 \%$ (Abbade et al., 2010). The deceleration interval (IV) was observed from the $105^{\text {th }}$ to the $120^{\text {th }}$ day, with low biomass increase (F1: 4.9\%, 6-156-6: 6.8\%).

The stationary phase (V) was observed between the $120^{\text {th }}$ day and $135^{\text {th }}$ day of culture $(\mathrm{F} 1$ : 2.4\%, 6-156-6: 3.2\%). In Jatropha curcas calli, cultivated for secondary compounds, the stationary phase was observed in a similar period (120 to 130 days) (Costa et al., 2015). After this period, there was no significant increase in the yerba mate callus biomass ( $p>0.01$. F1: 1.2\%.6-156-6: 1. 6\%).

Previous research suggested that the extraction of secondary metabolites from callus cultures should be carried out during the stationary phase, because in this period the production of the 
primary metabolites (important for the cellular development) practically ceases and the secondary metabolites are produced (Smith, 1992).

\section{Polyphenols and methylxanthines}

Figure No. 3 shows the characteristic chromatogram of the hydro-alcoholic extracts of yerba mate calli and leaves. Compounds 1 and 3 were identified as theobromine and caffeine, respectively. These two compounds belong to the group of methylxanthines and are representative of yerba mate (Filip et al., 1998).
Peaks 25,6 and 7 were identified as chlorogenic acid, 3,4-dicaffeoylquinic acid, 3,5dicaffeoylquinic acid and 4,5-dicaffeoylquinic acid, respectively. Chlorogenic acids and isomers of dicaffeoylquinic acid have been previously described in yerba mate and have been reported as the major constituents of its leaves (Filip et al., 2001; Bravo et al., 2007). Rutin was identified in the leaves of both clones, at concentrations of $3.2 \mathrm{mg} . \mathrm{g}^{-1}$ and $4.7 \mathrm{mg} . \mathrm{g}^{-1}$, respectively for F1 and 6-156-6. However, in callus, the concentration of this compound was lower than 1 $\mathrm{mg} \cdot \mathrm{g}^{-1}$.
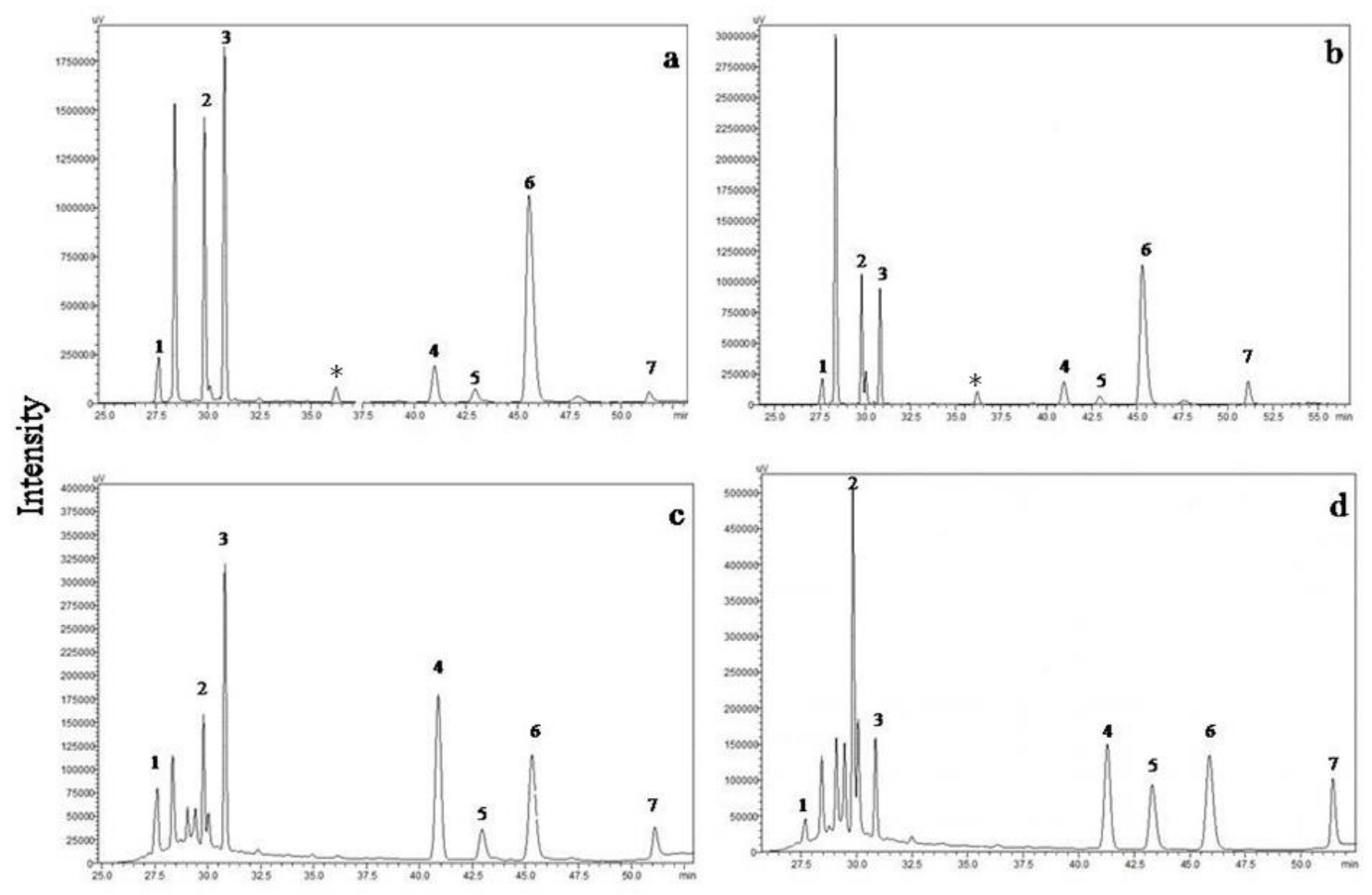

Retention time (min)

Figure No. 3

Chromatogram of the compounds present in: a) leaves of clone F1, b) leaves of clone 6-156-6, c) calli of clone F1 cultured for 120 days in culture medium, $d$ ) calli of clone 6-156-6 cultured for 120 days in culture medium. Retention time (min): 1- theobromine (27.5), 2- chlorogenic acid (29.8), 3- caffeine (30.8), 4-IS, umbelliferone (41.0), 5- 3,4dicaffeoylquinic acid (42.8), 6- 3,5-dicaffeoylquinic acid (45.5), 7- 4,5-dicaffeoylquinic acid (51.2),

* Rutin $(36,5)$ - only detected in leaves

Culture time affected the contents of chlorogenic acid and 3,5-dicaffeoylquinic acid $(p<0.05$, Figure No. 4$)$ in yerba mate calli as well as caffeine and theobromine, although it was not possible to adjust a significant regression model for these last two compounds. Caffeine was the most abundant secondary compound in calli of 6-156-6 clone, with an average of $9.11 \mathrm{mg} \cdot \mathrm{g}^{-1}$ at 135 days (Table No. 1). In calli of F1 clone, the most abundant compound was 3,5-dicaffeoylquinic acid, with 4.79 $\mathrm{mg} \cdot \mathrm{g}^{-1}$ at 135 days of cultivation.

Boletín Latinoamericano y del Caribe de Plantas Medicinales y Aromáticas / 553 
Table No. 2

Secondary compounds quantitative determination of yerba mate calli from two clones at different growth periods

\begin{tabular}{|c|c|c|c|c|c|}
\hline \multirow[b]{2}{*}{ Clone } & \multirow[b]{2}{*}{ Time (days) } & \multicolumn{4}{|c|}{ Compound } \\
\hline & & Theo (mg.g-1) & 3-CQA (mg.g $\left.{ }^{-1}\right)$ & Caf $\left(\mathrm{mg} \cdot \mathrm{g}^{-1}\right)$ & 3,5-diCQA (mg.g $\left.{ }^{-1}\right)$ \\
\hline \multirow{6}{*}{$\mathrm{F} 1$} & 75 & $1.03 \pm 0.30$ & $0.56 \pm 0.12$ & $1.44 \pm 0.54$ & $2.32 \pm 0.28$ \\
\hline & 90 & $1.63 \pm 0.25$ & $0.33 \pm 0.08$ & $2.62 \pm 0.15$ & $0.71 \pm 016$ \\
\hline & 105 & $1.08 \pm 0.01$ & $0.034 \pm 0.01$ & $1.42 \pm 0.04$ & $0.07 \pm 0.09$ \\
\hline & 120 & $1.20 \pm 0.04$ & $1.57 \pm 0.34$ & $3.42 \pm 0.58$ & $3.89 \pm 1.17$ \\
\hline & 135 & $1.42 \pm 0.23$ & $2.05 \pm 0.87$ & $4.25 \pm 0.34$ & $4.79 \pm 0.06$ \\
\hline & 150 & $1.04 \pm 0.26$ & $0.15 \pm 0.05$ & $1.41 \pm 0.31$ & $0.39 \pm 0.19$ \\
\hline \multirow{6}{*}{$6-156-6$} & 75 & $0.68 \pm 0.04$ & $1.18 \pm 0.32$ & $2.78 \pm 0.27$ & $4.27 \pm 0.71$ \\
\hline & 90 & $0.84 \pm 0.09$ & $1.32 \pm 0.68$ & $3.09 \pm 0.28$ & $2.99 \pm 1.51$ \\
\hline & 105 & $0.55 \pm 0.10$ & $1.87 \pm 0.19$ & $2.77 \pm 0.29$ & $2.79 \pm 0.44$ \\
\hline & 120 & $0.58 \pm 0.05$ & $3.97 \pm 1.57$ & $2.10 \pm 0.09$ & $3.32 \pm 0.77$ \\
\hline & 135 & $0.27 \pm 0.06$ & $1.76 \pm 0.53$ & $9.11 \pm 0.60$ & $5.96 \pm 1.2$ \\
\hline & 150 & $0.51 \pm 0.05$ & $0.57 \pm 0.27$ & $3.13 \pm 0.52$ & $1.73 \pm 0.22$ \\
\hline
\end{tabular}

Means \pm Standard deviation. Theo= theobromine; 3-CQA= chlorogenic acid; Caf=caffeine; 3,5-diCQA = 3,5dicaffeoylquinic acid

The lowest content of 3,5-dicaffeoylquinic acid in calli of F1 clone occurred at 105 days of culture, during the exponential growth phase. The contents were present in concentrations 68 times lower than those observed at the peak production.
These results agree with those observed in callus culture of Rosmarinus officinalis during the linear growth phase, which resulted in low levels of rosmarinic acid (Yesil-celiktas et al., 2007).

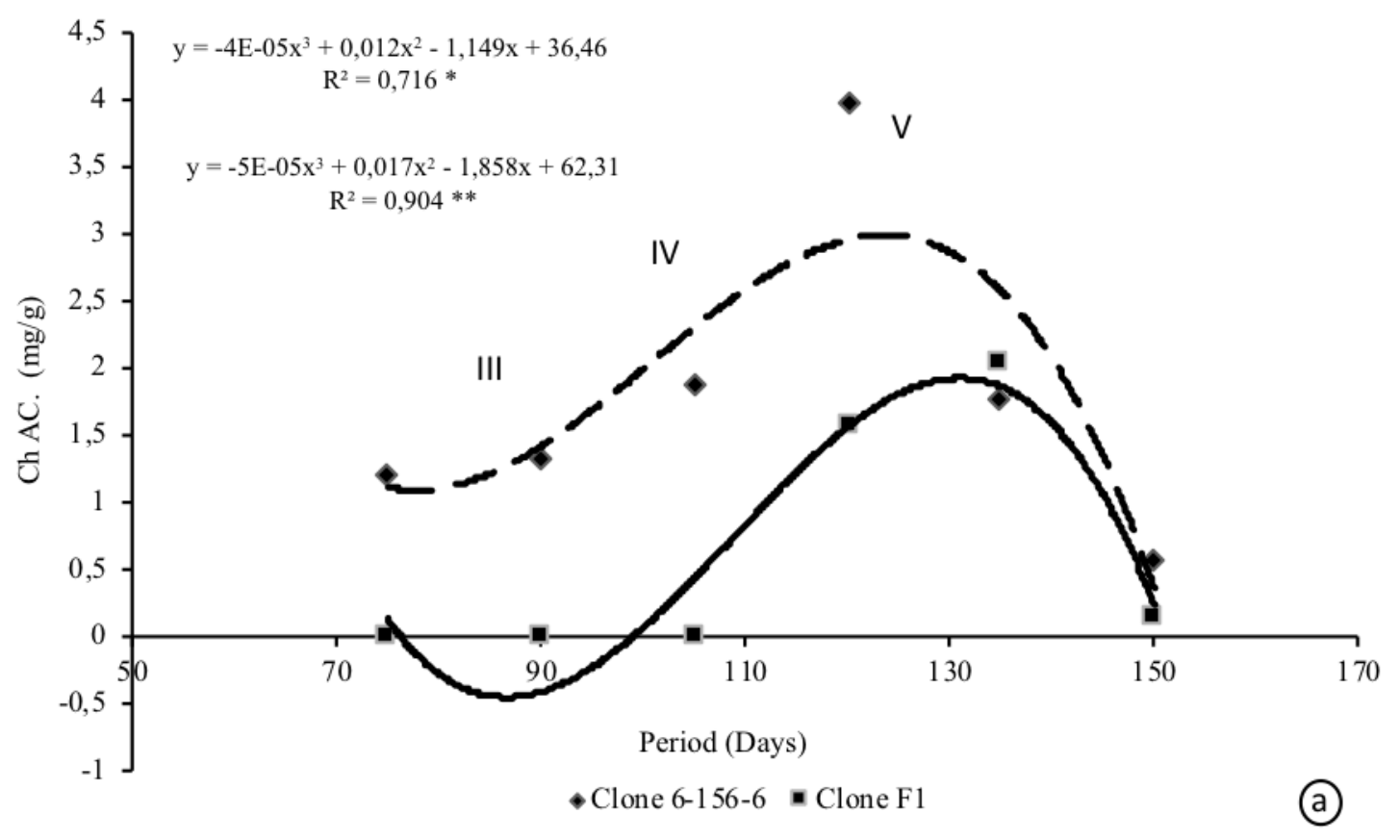

Boletín Latinoamericano y del Caribe de Plantas Medicinales y Aromáticas / 554 


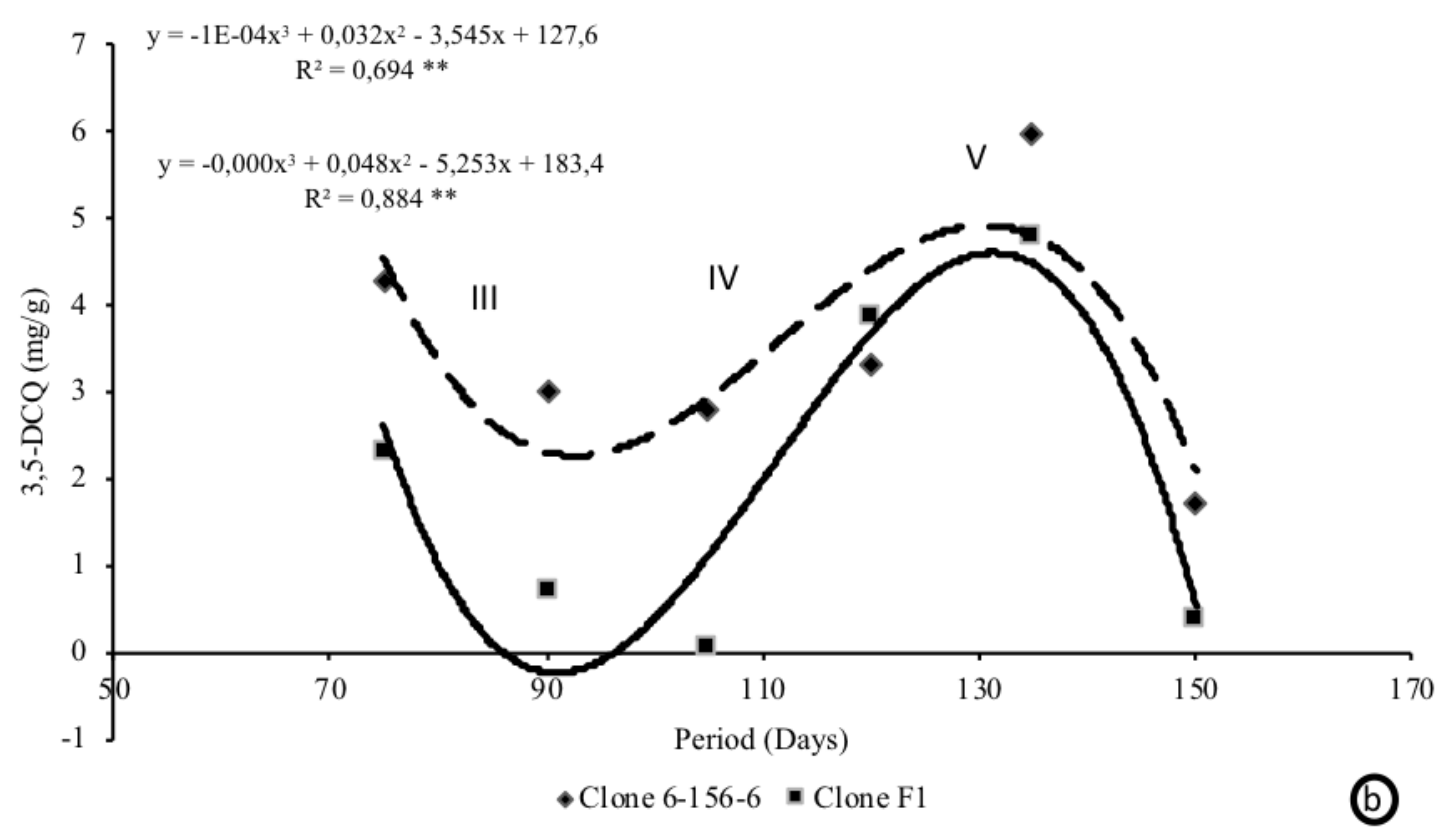

Figure No. 4

Content of chlorogenic acid (a) and 3,5-dicaffeoylquinic acid (b) in different growth periods in yerba mate calli Phases: III - linear, IV - deceleration, V -stationary

For both chlorogenic and 3,5dicaffeoylquinic acids in both clones, the highest production occurred during calli stationary growth phase, followed by a pronounced drop at 150 days. Due to the low growth presented it is possible to infer that calli in this period entered in a decline phase, characterized by loss of biomass loss, followed by cell death (Santos et al., 2017). The chromatographic profiles of calli samples were similar, varying only on peak intensity as a function of the culture time (Figure No. 3). Compounds 5 and 7, at significant concentrations in calli of both clones, were identified by UV and LC-MS/MS as 3,4-dicaffeoylquinic acid and 4,5-dicaffeoylquinic acid, respectively (Grunennvaldt et al., 2020).

\section{Total phenolic compounds}

Regardless of callus culture time, a significant difference was observed on phenolic compounds between clones: average of $43.3 \mathrm{mg} \mathrm{GAE}^{-1}{ }^{-1}$ for 6$156-6$ clone and $39.3 \mathrm{mg} \mathrm{GAE} \cdot \mathrm{g}^{-1}$ for the $\mathrm{F} 1$ clone $(p$ $<0.01)$. However, no significant difference $(p>0.05)$ was observed on total phenolic compounds in leaves of the two clones of yerba mate (average 157.35 mgGAE. $\left.g^{-1}\right)$.

The lower total phenolic values in calli compared to leaves can be explained by the loss of tissue differentiation during callus formation, along with the brief stationary phase that callus cultures present. Besides this, an inhibition or insufficient distribution of enzymes necessary for the synthesis of secondary compounds in the cells of the cultivated callus may occur ( Muhitch \& Fletcher, 1985; Amaral \& Silva, 2003).

Total phenolics in calli of 6-156-6 clone remained constant until 105 days, followed by increase up to 135 days and a later decrease at 150 days. For calli of F1 clone, total phenolic content decreased 1.2 times at 105 days, when compared to 90 days of growth (Figure No. 5). At 105 days, calli were in the linear phase of growth, characterized by a greater demand of carbon and energy, and, therefore, the biosynthesis of primary metabolites was possibly favored in detriment of secondary compounds (Santos-Gomes, 2003). 


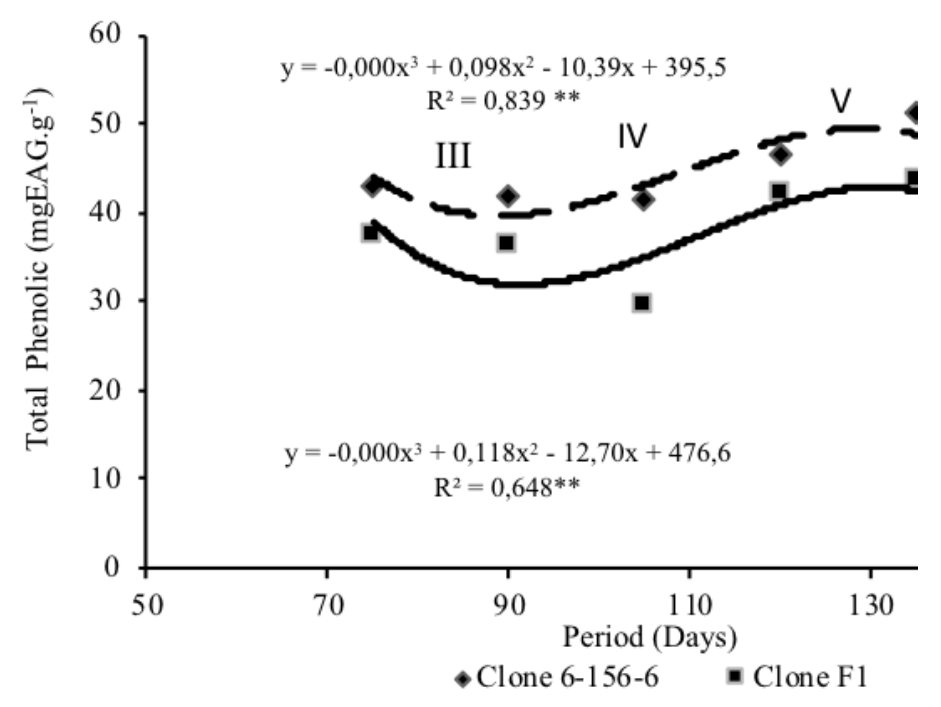

Figure No. 5

Content of total phenolic compounds in different growth periods of yerba mate callus culture. Phases: III - linear, IV - deceleration, V - stationary

In both clones, the highest production of phenolic compounds occurred around 135 days (F1: 43.7 mgGAE.g ${ }^{-1}$; 6-156-6:51.1 mgGAE.g ${ }^{-1}$ ), in the stationary phase. Typically, the peak production of secondary metabolites occurs during the late stationary phase and is associated with inhibition of cell growth and the production of secondary metabolism enzymes (Pradeep et al., 2015; OchoaVillarreal et al., 2016).

\section{Antioxidant activity}

On average, calli of 6-156-6 clone showed antioxidant activity 1.4 times higher than F1 genotype $(\mathrm{p}<0.01)$. The highest antioxidant activity was observed at 120 days of calli growth, for both clones, with an average of $89.4 \%$ of DPPH radical scavenging activity. For leaves, no difference $(p>$ $0.05)$ was observed between the 6-156-6 and F1 genotypes $(92.2 \%)$. Leaves had higher antioxidant activity $\left(216.7 \mu\right.$ molTE. $\left.^{-1}\right)$ than 120 -day calli (104.6 $\mu$ molTE. $\left.\mathrm{g}^{-1}\right)$. A similar result was observed in Cynara cardunculus leaves, which showed higher antioxidant activity than calli of the same species (Trajtemberg et al., 2006).

Antioxidant activity across culture time presented different tendecies for the two clones (Figure No. 6). Calli of 6-156-6 clone showed constant activity up to 135 days, with a decline of 1.5 times at 150 days compared to the period of greatest radical scavenging capacity.

Calli of the F1 clone presented a decline in antioxidant activity at 90 days (1.2 times) followed by an abrupt decline at 105 days. Subsequently, an increase in antioxidant activity of almost 8 times was observed, with the greatest DPPH radical scavenging activity at 120 days. In both genotypes, the highest free radical scavenging activity occurred during the calli stationary phase, at which both clones presented similar activity, around $100 \mu$ mol.g-1TE. 


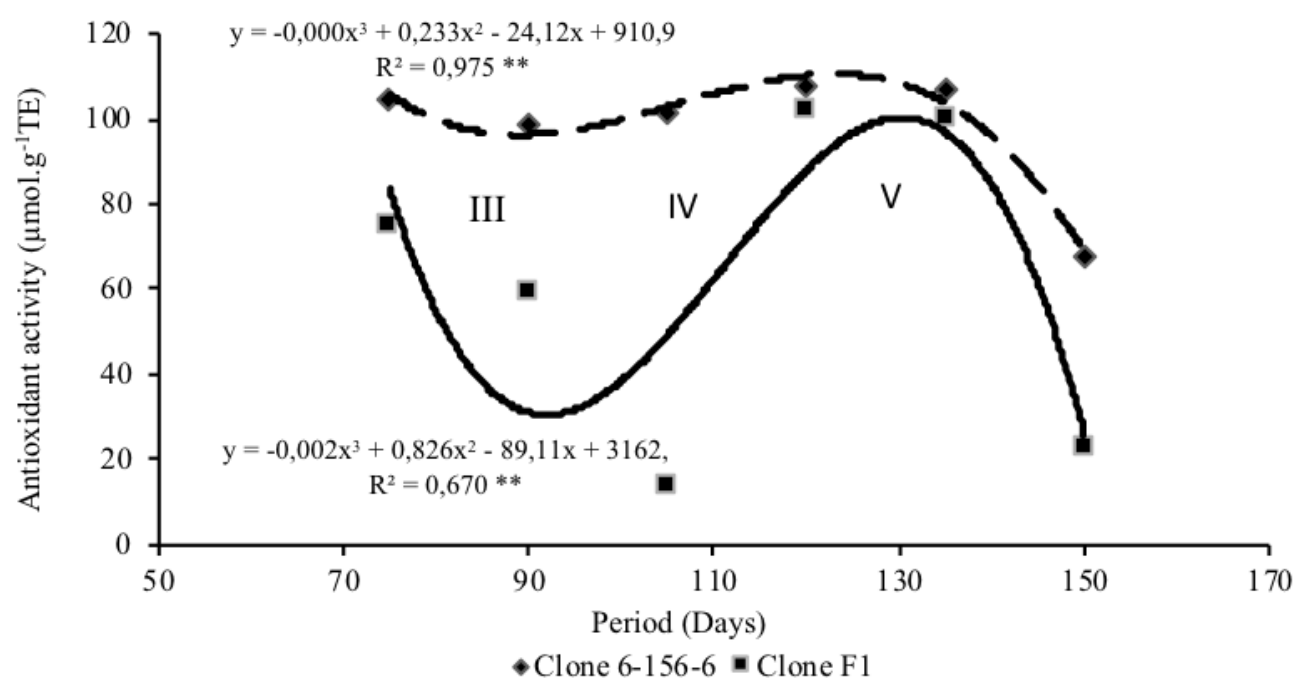

Figure No. 6

DPPH radical scavenging activity in different growth periods of yerba mate calli. Phases: III - linear, IV - deceleration, V -stationary

\section{Correlation analysis}

Table No. 2 shows the Pearson correlation coefficients between the variables assessed in this work. There is an obvious positive correlation between total phenolic compounds and antioxidant activity. The antioxidant properties of polyphenols are attributed to their redox properties, acting as reducing agents, hydrogen donators, metal chelators and single oxygen quenchers (Piluzza et al., 2011). Chlorogenic acid is one of the phenolic compounds observed in callus cultures of yerba mate, which have been previously reported as largely responsible for the antioxidant potential of $I$. paraguariensis extracts (Anesini et al., 2012).

In the present study, however, the positive correlation between 3,5-dicaffeoylquinic acid and antioxidant activity was higher than the correlation observed between chlorogenic acid and free radical scavenging capacity (Table No. 2). This may be due to the fact that dicaffeoylquinic acids have two phenolic rings compared to one in monocaffeoylquinic acids such as chlorogenic acid (Wang et al., 2003).

A positive correlation between 3,5dicaffeoylquinic acid content and caffeine was also observed. Caffeoylquinic acids are capable of sequestering caffeine in the vacuole and forming complexes with phenylpropanoids (Waldhauser \& Baumann, 1996). These phenomena may also explain the observed correlation of caffeine with the total phenolic content.

Table No. 2

Correlation among secondary compounds, total phenolic content and antioxidant activity of Ilex paraguariensis calli cultured in vitro

\begin{tabular}{|c|c|c|c|c|c|}
\hline & $\begin{array}{l}\text { 3-CQA } \\
\left(\mathrm{mg} \cdot \mathrm{g}^{-1}\right)\end{array}$ & $\begin{array}{c}\text { Caf } \\
\left(\mathrm{mg} \cdot \mathrm{g}^{-1}\right)\end{array}$ & $\begin{array}{c}\text { 3,5-diCQA } \\
\left(\mathrm{mg} \cdot \mathrm{g}^{-1}\right)\end{array}$ & $\begin{array}{c}\text { DPPH } \\
\left(\mu \mathrm{mol} . \mathrm{g}^{-1} \mathrm{TE}\right)\end{array}$ & 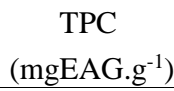 \\
\hline Theo (mg.g $\left.{ }^{-1}\right)$ & -0.128 & -0.394 & -0.386 & -0.362 & -0.490 \\
\hline 3-CQA (mg.g $\left.\mathrm{g}^{-1}\right)$ & & 0.077 & 0.455 & 0.676 & 0.680 \\
\hline Caf $\left(m g \cdot g^{-1}\right)$ & & & 0.745 & 0.490 & 0.728 \\
\hline 3,5-diCQA (mg.g $\left.{ }^{-1}\right)$ & & & & 0.875 & 0.931 \\
\hline DPPH $\left(\mu \mathrm{mol} . \mathrm{g}^{-1} \mathrm{TE}\right)$ & & & & & 0.921 \\
\hline
\end{tabular}

Theo = theobromine; 3-CQA= chlorogenic acid; $\mathrm{Caf}=$ caffeine; $\mathrm{DPPH}=$ antioxidant activity; 3,5-diCQA = 3,5-dicaffeoylquinic acid; $T P C=$ total phenolic

Boletín Latinoamericano y del Caribe de Plantas Medicinales y Aromáticas / 557 
The interest for natural products is growing due largely to the restrictions on addition of synthetic compounds in drugs, cosmetics and foods (OchoaVillarreal et al., 2016). Although there is apparently lower accumulation of secondary compounds in callus compared to yerba mate leaves, the production under in vitro conditions can be widely applied in pharmaceutical compositions, with the advantage of having the controlled production of these natural molecules throughout the year.

\section{CONCLUSION}

Extracts from yerba mate calli have potential for the production of valuable compounds, such as chlorogenic acid and 3,5-dicaffeoylquinic acid, with high antioxidant activity. Calli stationary growth phase is when the highest content of these compounds occurs.

There is a difference between genotypes for the production of secondary compounds in yerba mate calli. Calli of 6-156-6 clone have a higher accumulation of caffeine, chlorogenic acid, and 3,5- dicaffeoylquinic acid, whereas, calli of F1 clone accumulate more theobromine.

The leaves of clones 6-156-6 and F1 do not differ in the concentration of secondary compounds, although the content of these compounds was higher in the leaves than in the calli. Yerba mate calli are capable of producing secondary compounds even under favorable conditions for growth and future studies focusing on increasing the production of these compounds by elicitation should be carried out.

\section{ACKNOWLEDGEMENTS}

The authors would like to thank the Federal University of Parana, the University of the Sunshine Coast, and the Brazilian Agricultural Research Corporation (EMBRAPA - Forestry). We also thank Trong Tran for the support with the LC-MS-MS analyses.

This work was supported by the Brazilian Federal Agency for Support and Evaluation of Graduate Education (CAPES) (PDSE/proc. $\mathrm{N}^{\circ}$ 88881.131659/2016-01 and DOC_PLENO/proc. $\mathrm{N}^{\circ}$ 88881.129327/2016-01).

\section{REFERENCES}

Abbade LC, Paiva PDDO, Paiva R, Graciano MH. 2010. Growth curve and biochemical analyses of callus of ipêbranco (Tabebuia roseoalba (Ridl) Sand). Naturalia 33: 45 - 56.

Amaral CLF, da Silva AB. 2003. Melhoramento biotecnológico de plantas medicinais. Rev Biotecnol Ciênc Desenvolv 30: 55 - 59 .

Anesini C, Turner S, Cogoi L, Filip R. 2012. Study of the participation of caffeine and polyphenols on the overall antioxidant activity of mate (Ilex paraguariensis). LWT - Food Sci Technol 45: 299 - 304. https://doi.org/10.1016/j.lwt.2011.06.015

Brand-Willians W, Cuvelier ME, Berset C. 1995. Use of a free radical method to evaluate antioxidant activity. LWT - Food Sci Technol 28: 25 - 30.

Bravo L, Goya L, Lecumberri E. 2007. LC/MS characterization of phenolic constituents of mate (Ilex paraguariensis, St Hil.) and its antioxidant activity compared to commonly consumed beverages. Food Res Int 40: 393 - 405. https://doi.org/10.1016/j.foodres.2006.10.016

Cardozo Junior EL, Morand C. 2016. Interest of mate (Ilex paraguariensis A. St.-Hil.) as a new natural functional food to preserve human cardiovascular health - A review. J Funct Foods 21: 440 - 454. https://doi.org/10.1016/j.jff.2015.12.010

Costa JL, da Silva ALL, Bier MCJ, Brondani GE, Gollo AL, Letti LAJ, Erasmo EAL, Soccol CR. 2015. Callus growth kinetics of physic nut (Jatropha curcas L.) and content of fatty acids from crude oil obtained in vitro. Appl Biochem Biotechnol 176: 892 - 902. https://doi.org/10.1007/s12010-015-1618-y

de Mejía EG, Song YS, Heck CI, Ramírez-Mares M. 2010. Yerba mate tea (Ilex paraguariensis): Phenolics, antioxidant capacity and in vitro inhibition of colon cancer cell proliferation. J Funct Foods 2: 23 - 34. https://doi.org/10.1016/j.jff.2009.12.003

Feitosa LS, Santos A, Arrigoni-blank MDF. 2013. Indução e análise histológica de calos em explantes foliares de Jatropha curcas L . (Euphorbiaceae). Biosci J 29: 370 - 377.

Filip R, Lopez P, Coussio J, Ferraro G. 1998. Mate substitutes or adulterants: Study of xanthine content. Phytother Res 12: 129 - 131. https://doi.org/10.1002/(SICI)1099-1573(199803)12:2<129::AID-PTR191>3.0.CO;2-1

Filip R, López P, Giberti G, Coussio J, Ferraro G. 2001. Phenolic compounds in seven South American Ilex 
species. Fitoterapia 72: 774 - 778. https://doi.org/10.1016/S0367-326X(01)00331-8

Gugliucci A. 1996. Antioxidant effects of Ilex Paraguariensis: induction of decreased oxidability of human LDL in vivo. Biochem Biophys Res Commun 344: 338 - 344.

Grunennvaldt RL, Degenhardt-Goldbach J, Brooks P, Tomasi JC, Hansel FA, Tran T, Gomes EN, Deschamps C. 2020. Callus culture as a new approach for the production of high added value compounds in Ilex paraguariensis: genotype influence, medium optimization and compounds identification. An Acad Bras Cienc 92: 1 - 16. http://doi.org/10.1590/0001-765202020181251

Horžić D, Komes D, Belščak A, Ganić KK, Iveković D, Karlović D. 2009. The composition of polyphenols and methylxanthines in teas and herbal infusions. Food Chem 115: 441 - 448.

https://doi.org/10.1016/j.foodchem.2008.12.022

Matsumoto RLT, Bastos DHM, Mendonça S, Nunes VS, Bartchewsky W, Ribeiro ML, Carvalho PO. 2009. Effects of mate tea (Ilex paraguariensis) ingestion on mRNA expression of antioxidant enzymes, lipid peroxidation, and total antioxidant status in healthy young women. J Agric Food Chem 57: 1775 - 1780.

Muhitch MJ, Fletcher JS. 1985. Influence of culture age and spermidine treatment on the accumulation of phenolic compounds in suspension cultures. Plant Physiol 78: 25 - 28. https://doi.org/10.1104/pp.78.1.25

Murashige T, Skoog F. 1964. A revised medium for rapid growth and bioessays with tobacco tissue cultures. Physiol Plant 15: 473 - 479.

Ochoa-Villarreal M, Howat S, Hong S, Jang MO, Jin YW, Lee EK, Loake GJ. 2016. Plant cell culture strategies for the production of natural products. BMB Rep 49: 149 - 158.

https://doi.org/10.5483/BMBRep.2016.49.3.264

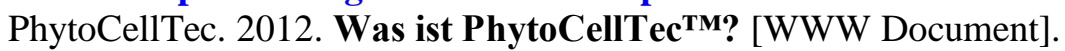
https://www.phytocelltec.ch/was-ist-phytocelltec

Piluzza G, Bullitta S, 2011. Correlations between phenolic content and antioxidant properties in twenty-four plant species of traditional ethnoveterinary use in the Mediterranean area. Pharm Biol 49: 240 - 247. https://doi.org/10.3109/13880209.2010.501083

Pradeep C, Kumar PM, Prava BJ. 2015. Effect of plant growth regulators on suspension culture of Adhatoda vasica nees. World J Pharm Res 9: 906 - 913.

Resende MDV, Sturion JA, Carvalho AP, Simeão RM, Fernandes JSC. 2000. Programa de melhoramento da ervamate coordenado pela EMBRAPA resultados da avaliação genética de populações, progênies, indivíduos e clones. Circ Técnica 43: 1 - 67.

Santos CG, Paiva R, Paiva PD, Paiva E. 2008. Indução e análise bioquímica de calos em segmentos foliares e nodais de Coffea canephora L. Cv. Apoatã. Magistra 20: 22 - 29.

Santos CG, Paiva R, Paiva PDDO, Paiva E. 2003. Indução e análise bioquímica de calos obtidos de segmentos foliares de Coffea arabica L ., Cultivar Rubi. Ciênc Agrotecnol 27: 571 - 577.

Santos MRA, de Souza CA, Paz ES. 2017. Growth pattern of friable calluses from leaves of Capsicum annuum var. annuum cv. Iberaba Jalapeño. Rev Ciênc Agron 48: 523 - 530. https://doi.org/10.5935/1806-6690.20170061

Silva FAS, de Azevedo CAV. 2016. The assistat software Version 7.7 and its use in the analysis of experimental data. Afr J Agric Res 11: 3733-3740. https://doi.org/10.5897/AJAR2016.11522

Smith R. 1992. Plant tissue culture: techniques and experiments. Academic Press, San Diego, USA.

Stachevski TW, Franciscon L, Degenhardt-Goldbach J. 2013. Efeito do meio de cultura na calogênese in vitro a partir de folhas de erva-mate. Pesq Florest Bras 33: 339 - 342. https://doi.org/10.4336/2013.pfb.33.75.441

Trajtemberg SP, Apóstolo NM, Fernández G. 2006. Calluses of Cynara cardunculus var. cardunculus cardoon (Asteraceae): determination of cynarine and chlorogenic acid by automated high-performance capillary electrophoresis. Vitr Cell Dev Biol - Plant 42: 534 - 537. https://doi.org/10.1079/IVP2006803

Trehan S, Michniak-Kohn B, Beri K. 2017. Plant stem cells in cosmetics: current trends and future directions. Future Sci 3. https://doi.org/10.4155/fsoa-2017-0026

Verardo G, Gorassini A, Ricci D, Fraternale D. 2016. High triterpenic acids production in callus cultures from fruit pulp of two apple varieties. Phytochem Anal 28: 5 - 15. https://doi.org/10.1002/pca.2638

Waldhauser SSM, Baumann TW. 1996. Compartmentation of caffeine and related purine alkaloids depends exclusively on the physical chemistry of their vacuolar complex formation with chlorogenic acids. 
Phytochemistry 42: 985 - 996. https://doi.org/10.1016/0031-9422(96)00072-6

Wang M, Simon JE, Aviles IF, He K, Zheng QY, Tadmor Y. 2003. Analysis of antioxidative phenolic compounds in artichoke (Cynara scolymus L.). J Agric Food Chem 51: 601 - 608. https://doi.org/10.1021/jf020792b

Yesil-Celiktas O, Nartop P, Gurel A, Bedir E, Vardar-Sukan F. 2007. Determination of phenolic content and antioxidant activity of extracts obtained from Rosmarinus officinalis calli. J Plant Physiol 164: 1536 1542. https://doi.org/10.1016/j.jplph.2007.05.013 